\title{
$V_{\text {max. }}$ activation of pp60-src tyrosine kinase from neuroblastoma Neuro-2A
}

\author{
Wayne T. MATTEN and Patricia F. MANESS* \\ Department of Biochemistry, University of North Carolina School of Medicine, Chapel Hill, NC 27514, U.S.A.
}

\begin{abstract}
A kinetic analysis of the tyrosine-specific protein kinase of $\mathrm{pp} 60^{\mathrm{c}-\mathrm{src}}$ from the $\mathrm{C} 1300$ mouse neuroblastoma cell line Neuro-2A and $\mathrm{pp} 60^{\mathrm{c} \cdot \mathrm{src}}$ expressed in fibroblasts was carried out to determine the nature of the increased specific activity of the neuroblastoma enzyme. In immune-complex kinase assays with $\mathrm{ATP}-\mathrm{Mn}^{2+}$ and the tyrosine-containing peptide angiotensin I as phosphoacceptor substrate, $\mathrm{pp} 60^{\mathrm{c} \text {-sre }}$ from the neuroblastoma cell line was characterized by a maximum velocity $\left(V_{\max }\right)$ that was $7-15$-fold greater than the $V_{\max }$ of pp60 $0^{\mathrm{c}-\mathrm{src}}$ from fibroblasts. The neuroblastoma enzyme exhibited $K_{\mathrm{m}}$ values for ATP $(16 \pm 3 \mu \mathrm{M})$ and angiotensin I $(6.8 \pm 2.6 \mathrm{mM})$ that were similar to $K_{\mathrm{m}}$ values for ATP $(25 \pm 3 \mu \mathrm{M})$ and angiotensin I $(6.5 \pm 1.7 \mathrm{~mm})$ of pp60 $0^{\mathrm{c}-\mathrm{src}}$ from fibroblasts. pp60 ${ }^{\mathrm{v}-\mathrm{src}}$ expressed in Rous-sarcoma-virus-transformed cells exhibited an ATP $K_{\mathrm{m}}$ value $(25 \pm 4 \mu \mathrm{M})$ and an angiotensin I $K_{\mathrm{m}}$ value $(6.6 \pm 0.5 \mathrm{~mm})$ that approximated the values determined for $\mathrm{pp} 60^{\mathrm{c} \cdot \mathrm{src}}$ in neuroblastoma cells and fibroblasts. These results indicate that the pp60 ${ }^{\mathrm{c}-\mathrm{src}}$ kinase from neuroblastoma cells has a higher turnover number than $\mathrm{pp} 60^{\mathrm{c}-\mathrm{src}}$ kinase from fibroblasts, and that the neural form of the enzyme would be expected to exhibit increased catalytic activity at the saturating concentrations of ATP that are found intracellularly.
\end{abstract}

\section{INTRODUCTION}

Proto-oncogenes are intensively studied because of their presumed roles in normal cell growth and development, in addition to their potential role in helping understand the processes of cell transformation. The function of the cellular $s r c$ (c-src) proto-oncogene is unknown, but several lines of evidence point to a role in neuronal cells. The protein product of c-src is a $63 \mathrm{kDa}$ protein $\left(\mathrm{pp} 60^{\mathrm{c}-\mathrm{src}}\right)$ with tyrosine-specific protein kinase activity $[1-3] . \mathrm{pp}^{6} 0^{\mathrm{c}-\mathrm{src}}$ is preferentially synthesized in neural tissues, with highest concentrations expressed in embryonic neural retina and brain [4,5]. In neural retina and cerebellum pp $60^{\mathrm{c}-\mathrm{src}}$ is expressed in neuronal cells at the onset of terminal differentiation when proliferation ceases, suggesting a role more closely linked to differentiation or function of neuronal cells than proliferation $[6,7]$. Immunocytochemical localization studies of pp60 $0^{\mathrm{c}-\mathrm{src}}$ in sensory neurons of chick dorsal-root ganglion cultures [8] and biochemical identification of pp60 $0^{\mathrm{c}-\mathrm{src}}$ in primary neuronal cultures from rat cerebral cortex [9] confirm that $\mathrm{pp} 60^{\mathrm{c}-\mathrm{src}}$ is a product of neuronal cells. However, pp60 ${ }^{\mathrm{c}-\mathrm{src}}$ is not restricted to neurons, as it is also expressed in neuroectodermal cells of early embryos [10], fibroblasts $[1,11,12]$ and astroglial-cell cultures [9].

It has been established that the $\mathrm{pp} 60^{\mathrm{c}-\mathrm{src}}$ protein kinase in neurons and neuroblastoma cells has an increased specific activity compared with $\mathrm{pp} 60^{\mathrm{c}-\mathrm{src}}$ in fibroblasts and glial cells. Primary cultures of rat cortical neurons express a structurally modified form of $\mathrm{pp} 60^{\mathrm{c}-\mathrm{src}}$ with specific kinase activity 6-12-fold greater than astrocytes from the same tissue, measured in the presence of subsaturating substrate concentrations [9]. Human neuroblastoma cell lines also produce a form of $\mathrm{pp} 60^{\mathrm{c}-\mathrm{src}}$ with a 20-40-fold higher specific tyrosine kinase activity than that of $\mathrm{pp} 60^{\mathrm{c}-\mathrm{src}}$ human glioblastoma cell lines or fibroblasts [13].
To investigate the basis for the higher pp60 $0^{\text {c-src }}$ kinase specific activity in cells of neural origin, we carried out a kinetic analysis of the protein kinase activity of $p p 60^{c-s r c}$ from the $\mathrm{C} 1300$ mouse neuroblastoma cell line Neuro$2 \mathrm{~A}$ and a mouse fibroblast line that overexpresses pp60 ${ }^{\text {c-src }}$. The Neuro-2A cell line is a clone derived from the spontaneously arising mouse neuroblastoma C1300 of sympathetic origin [14-16] that maintains differentiated neuronal functions, as indicated by neuronal morphology and expression of tyrosine hydroxylase [17]. The NIH(pMcsrc/cos)A cell line is a clone of NIH 3T3 mouse fibroblasts that overexpresses $\mathrm{pp} 60^{\mathrm{c}-\mathrm{src}}$ from a cloned chicken c-src gene introduced into the cells by transfection [18]. We demonstrate in the present paper that $\mathrm{pp} 60^{\mathrm{c}-\mathrm{src}}$ from the neuroblastoma cell line is a tyrosine-specific protein kinase, whose phosphotransferase activity is characterized by a $V_{\max }$ that is $7-15$-fold higher than that of $\mathrm{pp} 60^{\mathrm{c}-\mathrm{src}}$ in the fibroblast cell line with only minor differences in $K_{\mathrm{m}}$ values for the phosphodonor or phospho-acceptor substrates. These results suggest that the neural form of $\mathrm{pp} 60^{\mathrm{c} \text {-src }}$ has a higher turnover number, allowing it to operate with enhanced catalytic efficiency even at the saturating concentrations of ATP present in cells.

\section{EXPERIMENTAL}

\section{Cell culture and method of extraction}

The mouse $\mathrm{C} 1300$ neuroblastoma Neuro-2A cell line was obtained from the American Type Culture Collection (Rockville, MD, U.S.A.). The NIH(pMcsrc/cos)A cell line was obtained from David Shalloway (Pennsylvania State University). The RR1022 cell line (American Type Culture Collection) is a rat tumour cell expressing the product of the src gene of Rous sarcoma virus (SchmidtRuppin strain). Neuro-2A neuroblastoma cells were

* To whom correspondence should be addressed. 
grown in $100 \mathrm{~mm}$-diam. tissue-culture plates to $80 \%$ confluence for no more than seven passages in Dulbecco's modified Eagle's medium containing $4.5 \mathrm{mg}$ of glucose/ $\mathrm{ml}, 15 \mathrm{~mm}$-Hepes, $50 \mu \mathrm{g}$ of gentamicin $/ \mathrm{ml}$ and $10 \%$ (v/v) fetal-calf serum (KC Biologicals, Lenexa, KS, U.S.A.) at $37^{\circ} \mathrm{C}$ in a $\mathrm{CO}_{2}$ /air $(1: 19)$ atmosphere. NIH(pMcsrc/cos)A and RR1022 cells were grown under the same conditions, substituting $5 \%$ calf serum (KC Biologicals) for fetal-calf serum.

For preparation of extracts, cells in tissue-culture dishes were washed three times in $0.15 \mathrm{M}-\mathrm{NaCl} / 10 \mathrm{~mm}$ potassium phosphate buffer, $\mathrm{pH} 7.0$, and were lysed at $4^{\circ} \mathrm{C}$ in $1 \mathrm{ml}$ of lysis buffer, which contained $20 \mathrm{~mm}$ potassium phosphate buffer, $\mathrm{pH} 7.0,1 \%(\mathrm{v} / \mathrm{v})$ Nonidet $\mathrm{P}-40,0.5 \%$ (w/v) sodium deoxycholate, $0.15 \mathrm{M}-\mathrm{KCl}$, 2 mM-sodium EDTA, 10 mM-NaF, 1 mm-sodium ATP, $200 \mu$ M-sodium orthovanadate, 100 kallikrein-inhibitor units of aprotinin $/ \mathrm{ml}$ and $2 \mathrm{mM}$ EGTA or $0.01 \%(w / v)$ leupeptin (Sigma Chemical Co.). After 20 strokes in a Dounce homogenizer, lysates were centrifuged at $10000 \mathrm{~g}$ for $30 \mathrm{~min}$ and the supernatants retained. The resulting cell extracts were stored at $-70^{\circ} \mathrm{C}$. No change in protein kinase activity resulted from storage at $-70^{\circ} \mathrm{C}$. Protein concentrations were determined by the Lowry method [19].

\section{Immune-complex protein kinase assays}

pp60 ${ }^{\text {-src }}$ phosphotransferase activity was determined by the immune-complex protein kinase assay with human angiotensin I acetate salt (Sigma Chemical Co.) as phospho-acceptor substrate and $\left[\gamma^{32} \mathrm{P}\right] \mathrm{ATP}-\mathrm{Mn}^{2+}$ as phospho-donor. pp $60^{\mathrm{c}-\mathrm{src}}$ was immunoprecipitated from cell extracts under conditions of antibody excess with mouse monoclonal antibody 327 [20]. This antibody was raised against bacterially expressed $\mathrm{pp60} \mathrm{v}^{\mathrm{v}-\mathrm{src}}$ and was obtained from Joan Brugge (State University of New York at Stony Brook). Monoclonal antibody 327 recognizes specifically the avian and mammalian forms of pp60 $60^{\mathrm{c}-\mathrm{src}}$ in normal uninfected cells, and $\mathrm{pp} 60^{\mathrm{v}-\mathrm{src}}$ in RSV-transformed cells [20]. Cell extracts $(1.4 \mathrm{mg}$ in $1 \mathrm{ml}$ of lysis buffer) were incubated for $2 \mathrm{~h}$ at $4^{\circ} \mathrm{C}$ with $2 \mu \mathrm{l}$ of ascites fluid $(0.1 \mathrm{mg} / \mathrm{ml})$ containing monoclonal antibody 327. Then $50 \mu \mathrm{l}$ of $50 \%(\mathrm{v} / \mathrm{v})$ goat anti-(mouse IgG) antibody-agarose (Sigma Chemical Co.) in lysis buffer was added to precipitate the immune complex. Immunoprecipitates were centrifuged in a microcentrifuge and washed four times in lysis buffer, once in $60 \mathrm{~mm}$-Tris/ $\mathrm{HCl}$ buffer, $\mathrm{pH} 7.2$, containing $2.5 \mathrm{M}-\mathrm{KCl}, 2 \mathrm{~mm}$-sodium EDTA, $10 \mathrm{~mm}-\mathrm{NaF}, \quad 50 \mu \mathrm{M}$-sodium orthovanadate, 2 mM-EGTA and 100 kallikrein-inhibitor units of aprotinin/ml, and twice in $20 \mathrm{~mm}-\mathrm{Tris} / \mathrm{HCl}$ buffer, pH 7.2, containing $5 \mathrm{~mm}-\mathrm{MnCl}_{2}, 50 \mu \mathrm{M}$-sodium orthovanadate, 100 kallikrein-inhibitor units of aprotinin $/ \mathrm{ml}$ and $0.1 \%(w / v)$ leupeptin. For measurement of specific activity, immunoprecipitates were divided into two equal portions. One half was used to measure kinase activity in the immune-complex protein kinase assay and the other half was used for immunoblotting to determine the amount of $\mathrm{pp} 60^{\mathrm{c}-\mathrm{src}}$ protein. For measurement of kinase activity, the washed pellets were prewarmed to $30^{\circ} \mathrm{C}$ and protein kinase reactions were initiated by adding a prewarmed solution $(25 \mu \mathrm{l})$ composed of $20 \mathrm{~mm}$-Tris/ $\mathrm{HCl}$ buffer, $\mathrm{pH} \mathrm{7.2,} \mathrm{containing} 5 \mathrm{~mm}-\mathrm{MnCl}_{2}, 5 \mathrm{~mm}-$ dithiothreitol, $50 \mu \mathrm{M}$-sodium orthovanadate, $0.286 \mathrm{mCi}$ of $\left[\gamma^{32} \mathrm{P}\right] \mathrm{ATP}(86 \mathrm{Ci} / \mathrm{mmol}$; New England Nuclear $) / \mathrm{ml}$ and various concentrations of unlabelled sodium ATP and angiotensin I, which were determined spectrophotometrically. Reactions were carried out for $20 \mathrm{~min}$ at $30^{\circ} \mathrm{C}$. Pilot experiments, which were carried out with pp60 ${ }^{\mathrm{c}-\mathrm{src}}$ from each cell type to establish initial-velocity conditions, showed that angiotensin I phosphorylation was linear with respect to time and extract concentration for at least $30 \mathrm{~min}$ at $30^{\circ} \mathrm{C}$. Reactions were terminated by chilling the tubes briefly on ice, centrifuging in a microcentrifuge to remove immune complexes containing the enzyme, and transferring supernatants to new tubes. Phosphorylated angiotensin $I$ in the supernatant was separated from reactants by binding to Whatman P81 phosphocellulose paper under acidic conditions as described by Glass et al. [21]. Briefly, $40 \mu 1$ of $5 \%$ (w/v) trichloroacetic acid was incubated with $20 \mu \mathrm{l}$ of the supernatant containing phosphorylated angiotensin I for $10 \mathrm{~min}$ on ice. Samples $(40 \mu \mathrm{l})$ of the acidified solutions were applied to $2 \mathrm{~cm} \times 2 \mathrm{~cm}$ squares of Whatman P81 paper, washed three times in $0.425 \%(\mathrm{v} / \mathrm{v}) \mathrm{H}_{3} \mathrm{PO}_{4}$, dried, and counted for ${ }^{32} \mathrm{P}$ radioactivity in Omnifluor (Dupont) in a scintillation counter.

To obtain the initial-velocity values $(v)$ used for determining kinetic constants, the total units of kinase activity in the immunoprecipitates ( $\mathrm{pmol} / \mathrm{min}$ ) were divided by the relative amount of $\mathrm{pp} 60^{\mathrm{c}-\mathrm{src}}$ in the immune complexes determined by immunoblotting. The amount of pp60 $60^{\mathrm{c}-\mathrm{src}}$ in the immune complexes was quantified in absorbance units by densitometric scanning of the $60 \mathrm{kDa}$ band on autoradiograms of immunoblots developed with monoclonal antibody 327 . Immunoblotting of immunoprecipitates from neuroblastoma Neuro-2A and $\mathrm{NIH}(\mathrm{pMcsrc} / \mathrm{cos}) \mathrm{A}$ cell extracts was performed on the same nitrocellulose filter to obtain absorbance units reflecting the relative amounts of $\mathrm{pp} 60^{\mathrm{c}-\mathrm{src}}$ protein.

\section{Western immunoblotting}

Washed immunoprecipitates were prepared as described for the immune-complex protein kinase assay, heated at $95^{\circ} \mathrm{C}$ for $1 \mathrm{~min}$ in SDS sample buffer without a thiol reducing agent, then centrifuged in a microcentrifuge. Supernatants were electrophoresed on $7.5 \%$ polyacrylamide gels $(9 \mathrm{~cm})$ containing a 1/37 weight ratio of bisacrylamide to acrylamide with the Laemmli system [22]. Non-reducing conditions were used because IgG heavy chains (53 kDa) are recognized by the ${ }^{125} \mathrm{I}-$ labelled secondary antibody, interfering with the detection of $\mathrm{pp} 60^{\mathrm{c}-\mathrm{src}}$ under reducing conditions. Proteins in the gels were electroblotted on to a nitrocellulose membrane $(9 \mathrm{~cm} \times 12 \mathrm{~cm})$ (Millipore) [23]. The nitrocellulose blot was incubated with a 1:20 dilution of monoclonal antibody 327 in a $0.8 \mathrm{ml}$ volume of $50 \mathrm{~mm}$ Tris/ $\mathrm{HCl}$ buffer, $\mathrm{pH} 7.2$, containing $150 \mathrm{~mm}-\mathrm{NaCl}$ and $0.5 \%$ (v/v) Tween-20 (Sigma Chemical Co.) [24] for $1 \mathrm{~h}$ at room temperature. The blot was washed five times $(200 \mathrm{ml})$ in the same buffer, incubated for $1 \mathrm{~h}$ at room temperature with $1 \mu \mathrm{Ci}$ of ${ }^{125}$ I-labelled anti-[mouse IgG $\mathrm{F}\left(\mathrm{ab}^{\prime}\right)_{2}$ ) fragment] antibody (5-20 Ci/mmol; Amersham/ Searle)/ml, washed as before and air-dried. ${ }^{125}$ I-labelled pp60 $0^{\mathrm{c}-\mathrm{src}}$ bands were detected by autoradiography on Dupont Cronex 6-plus X-ray film with Dupont Lightning Plus intensifying screens and quantified with an LKB 2202 Ultrascan laser densitometer. The time of film exposure was adjusted so that the intensity of an exposed region of film was within the linear range of response of the film to ${ }^{125}$ I, as standardized previously [25].

Densitometric scanning of Western immunoblots 


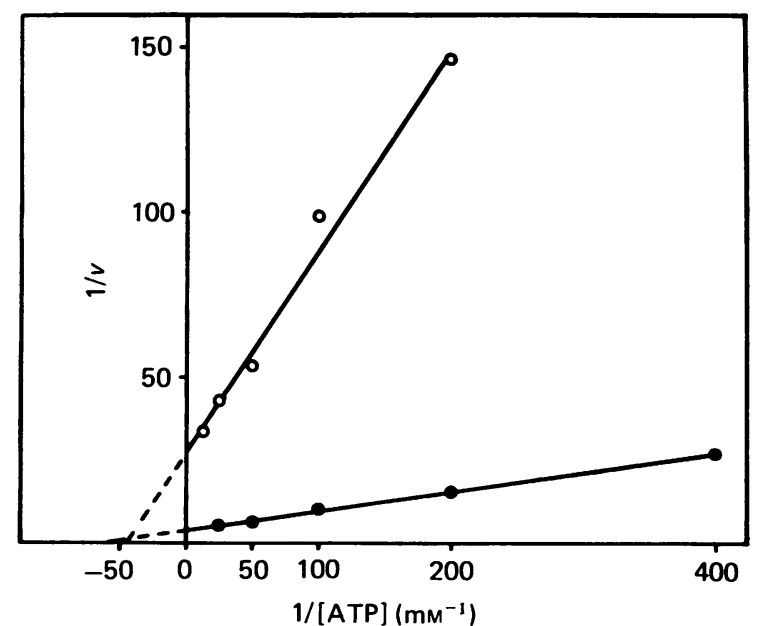

Fig. 1. Lineweaver-Burk plot of pp60 6 -ssc tyrosine kinase activity from neuroblastoma Neuro-2A and fibroblasts in immune-complex protein kinase assays with various concentrations of ATP and a fixed concentration of angiotensin I (20 mM)

Initial velocity $(v)$ indicates the number of pmol of phosphate transferred to angiotensin $\mathrm{I} / \mathrm{min}$ by an equal amount of $\mathrm{pp} 60^{\mathrm{c}-\mathrm{src}}$ protein in the immune complexes from

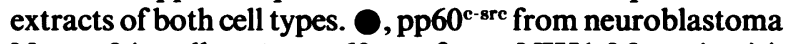
Neuro-2A cells; $O$, pp60 ${ }^{\text {-sre }}$ from NIH(pMcsrc/cos)A fibroblasts.

showed that there was approx. 20-fold more pp60 $60^{\mathrm{c}-\mathrm{src}}$ in immunoprecipitates from $1.4 \mathrm{mg}$ of NIH(pMcsrc/cos)Acell extract (14600 absorbance units/mg of extract protein) compared with the neuroblastoma extract (714 absorbance units $/ \mathrm{mg}$ of extract protein). It was necessary to employ a 20 -fold difference in amount of pp60 $0^{\mathrm{c} \text {-src }}$ from the two cell types in the immune-complex protein kinase assays to obtain approximately the same number of units of protein kinase activity. This ensured reliability in the measurements of total ${ }^{32} \mathrm{P}$ radioactivity (c.p.m.) transferred to angiotensin I at low ATP concentrations.

No difference in specific activity of pp60 $0^{\mathrm{c}-\mathrm{src}}$ immunoprecipitated from NIH(pMcsrc/cos)A-cell extracts was observed when extract concentrations were varied from $0.1 \mathrm{mg}$ to $1.4 \mathrm{mg}$ per $\mathrm{ml}$ of lysis buffer or when Neuro-2A extract concentrations were varied from $0.7 \mathrm{mg}$ to $1.4 \mathrm{mg}$ per $\mathrm{ml}$ in immune-complex kinase assays carried out at $20 \mu \mathrm{M}-\mathrm{ATP}-\mathrm{Mn}^{2+}$ and $10 \mathrm{mM}$ angiotensin $\mathrm{I}$. The amount of $\mathrm{pp} 60^{\mathrm{c}-\mathrm{src}}$ determined by immunoblotting was linear within this range of protein concentrations.

\section{Determination of enzyme kinetic constants}

$K_{\mathrm{m}}$ and $V_{\max }$ values and their standard errors were computed by the weighted least-squares method of Wilkinson [26]. The initial velocities and $V_{\max }$ values are relative values expressed as pmol of phosphate transferred to angiotensin $\mathrm{I} / \mathrm{min}$ by 1 absorbance unit of pp60 $0^{\mathrm{c}-\mathrm{src}}$. For determining background values, lysis buffer was substituted for cell extract, and immunecomplex protein kinase assays were carried out at the same fixed-substrate concentration and highest variedconcentration-substrate concentration used in the assay. Results of duplicate determinations were averaged and background values subtracted. At $40 \mu \mathrm{M}$-ATP the amount of ${ }^{32} \mathrm{P}$ transferred to angiotensin $\mathrm{I}$ in $20 \mathrm{~min}$ by pp60 ${ }^{\mathrm{c}-\mathrm{src}}$ from the neuroblastoma Neuro-2A-cell extract (1.4 mg) was 50710 c.p.m., of which 5650 c.p.m. represented the background. At $40 \mu \mathrm{M}-\mathrm{ATP}$ the amount of ${ }^{32} \mathrm{P}$ transferred to angiotensin $\mathrm{I}$ in $20 \mathrm{~min}$ by $\mathrm{pp} 60^{\mathrm{c}-\mathrm{src}}$ from the NIH(pMcsrc/cos)A-cell extract $(1.4 \mathrm{mg})$ was 61620 c.p.m., of which 5080 c.p.m. represented the background.

\section{RESULTS}

To determine if $\mathrm{pp} 60^{\mathrm{c}-\mathrm{src}}$ in mouse neuroblastoma Neuro-2A cells exhibited elevated tyrosine protein kinase activity, we determined $K_{\mathrm{m}}$ and $V_{\max }$. values for ATP and angiotensin $I$ in immune-complex protein kinase reactions catalysed by $\mathrm{pp}^{\mathrm{c}} 0^{\mathrm{c}-\mathrm{src}}$ from neuroblastoma Neuro-2A cells and from NIH(pMcsrc/cos)A fibroblasts. These assays used monoclonal antibody 327 raised against bacterially expressed pp60 $0^{\mathrm{v} \text {-src }}$ that recognizes the mammalian and avian forms of $\mathrm{pp} 60^{\mathrm{c}-\mathrm{sre}}$ in normal untransformed cells [20]. pp60 ${ }^{\mathrm{c}-\mathrm{src}}$ was immunoprecipitated from Neuro-2A-cell and NIH(pMcsrc/cos)A-cell extracts containing the same amount and concentration of protein. Phosphotransferase activity was measured with ATP- $\mathrm{Mn}^{2+}$ as phospho-donor and synthetic human angiotensin I peptide as phospho-acceptor substrate. Western immunoblots of immunoprecipitates from both cell types revealed a single major band at about $60 \mathrm{kDa}$, the expected size of pp60 $0^{\mathrm{c}-\mathrm{src}}$.

In the first experiment $K_{\mathrm{m}}$ and $V_{\max }$ values were determined with various concentrations of ATP- $\mathbf{M n}^{2+}$ and a fixed concentration of human angiotensin I peptide $(20 \mathrm{mM})$ that was near saturating. $\mathrm{Mn}^{2+}$ was used as bivalent cation because the activity of $\mathrm{pp} 60^{\mathrm{c}-\mathrm{src}}$ kinase

Table 1. Kinetic constants of pp60-are kinase from neuroblastoma cells and fibroblasts

Values for ATP were obtained at 20 mM-angiotensin I, and those for angiotensin I at $100 \mu \mathrm{M}-\mathrm{ATP}-\mathrm{Mn}^{2+} . V_{\max }$ is expressed as pmol of phosphate transferred to angiotensin $\mathrm{I} / \mathrm{min}$ by an equal amount of $\mathrm{pp} 60^{\mathrm{c}-\mathrm{src}}$ protein immunoprecipitated from Neuro2A-cell or NIH(pMcsrc/cos)A-cell extract as determined by Western immunoblotting. Values are given as means \pm S.E.M.

\begin{tabular}{lcclcc}
\hline \multirow{2}{*}{ Cell line } & \multicolumn{2}{c}{ ATP } & & \multicolumn{2}{c}{ Angiotensin I } \\
\cline { 2 - 3 } \cline { 6 - 7 } & $K_{\mathrm{m}}(\mu \mathrm{M})$ & $V_{\max .}$ & & $K_{\mathrm{m}}(\mathrm{mM})$ & $V_{\max .}$ \\
\hline Neuroblastoma (Neuro-2A) & $16 \pm 3$ & $273 \pm 23$ & & $6.8 \pm 2.6$ & $357 \pm 59$ \\
Fibroblast [NIH(pMcsrc/cos)A] & $25 \pm 3$ & $39 \pm 2$ & & $6.5 \pm 1.7$ & $23 \pm 2$
\end{tabular}




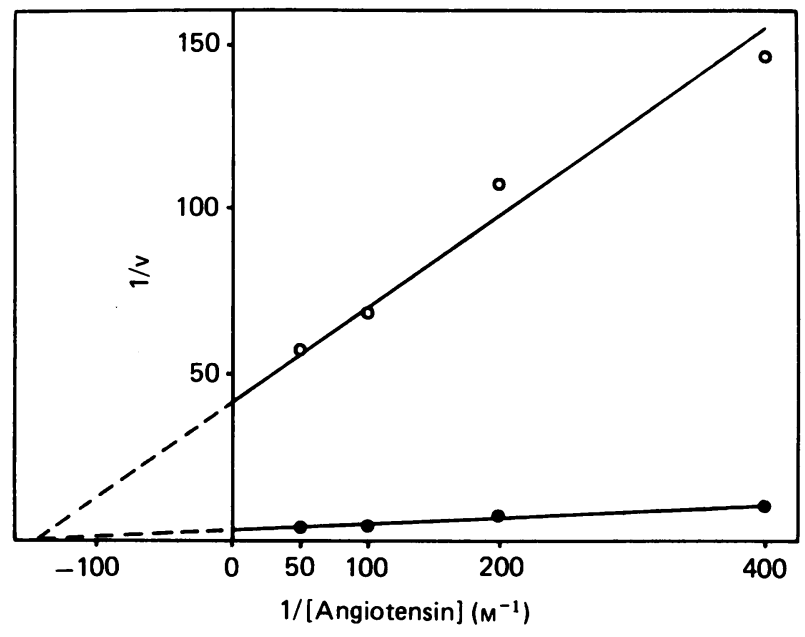

Fig. 2. Lineweaver-Burk plot of pp60-ac tyrosine kinase activity from neuroblastoma Neuro-2A and fibroblasts in immune-complex protein kinase assays with various concentrations of angiotensin I and a fixed concentration of ATP $(100 \mu \mathrm{M})$

Initial velocity $(v)$ indicates the number of pmol of phosphate transferred to angiotensin $\mathrm{I} / \mathrm{min}$ by an equal amount of pp60 ${ }^{\mathrm{c}-\mathrm{src}}$ protein in the immune complexes from extracts of both cell types., $\mathrm{pp} 60^{\mathrm{c}-\mathrm{src}}$ from neuroblastoma Neuro-2A cells; $O,{\text { pp } 60^{\text {c-sre }}}$ from $\mathrm{NIH}(\mathrm{pMcsrc} / \mathrm{cos}) \mathrm{A}$ fibroblasts.

was found to be significantly greater with $\mathrm{Mn}^{2+}$ than $\mathrm{Mg}^{2+}$, in agreement with other reports [27]. MichaelisMenten plots of initial velocity $(v)$ versus ATP

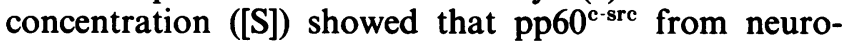
blastoma Neuro-2A cells and fibroblasts exhibited typical saturation kinetics, with no observable allosteric effect on kinase activity by ATP within the range of ATP concentrations used. Lineweaver-Burk plots revealed that $\mathrm{pp} 60^{\mathrm{c}-\mathrm{src}}$ kinase from Neuro-2A neuroblastoma cells had a maximum velocity that was 7 -fold greater than that of pp60 $0^{\text {c-src }}$ from fibroblasts (Fig. 1 and Table 1). In contrast, only very slight differences in ATP $K_{\mathrm{m}}$ values were observed between $\mathrm{pp} 60^{\mathrm{c}-\mathrm{src}}$ from neuroblastoma cells $(16 \mu \mathrm{M})$ and fibroblasts $(25 \mu \mathrm{M})$ (Fig. 1 and Table 1).

In the second experiment $K_{\mathrm{m}}$ and $V_{\max }$. values were determined with various concentrations of angiotensin I and a near-saturating concentration of ATP- $\mathbf{M n}^{2+}$ $(100 \mu \mathrm{M})$. Michaelis-Menten plots of initial velocity $(v)$ versus angiotensin I concentration ([S]) showed that the forms of $\mathrm{pp} 60^{\mathrm{c}-\mathrm{src}}$ kinase from neuroblastoma Neuro-2A cells and fibroblasts exhibited saturation kinetics with no observable allosteric effect on kinase activity by angiotensin I. Lineweaver-Burk plots revealed no significant difference in the angiotensin I $K_{\mathrm{m}}$ values for $\mathrm{pp} 60^{\mathrm{c}-\mathrm{src}}$ in the two cell types (Fig. 2 and Table 1). The angiotensin $K_{\mathrm{m}}$ values were approx. $7 \mathrm{~mm}$ for $\mathrm{pp} 60^{\mathrm{c}-\mathrm{src}}$ from both cell types. At the near-saturating concentration of ATP used in these experiments, the $V_{\max }$ for $\mathrm{pp} 60^{\mathrm{c}-\mathrm{src}}$ from neuroblastoma cells was approx. 15-fold greater than that of pp60 $0^{\text {-src }}$ from fibroblasts (Table 1), in accord with the increased $V_{\max }$. observed at the near-saturating concentration of angiotensin I (20 mM) used in the first experiment.
The $K_{\mathrm{m}}$ values for pp60 $0^{\text {e-src }}$ from Neuro-2A cells and fibroblasts were similar to the $K_{\mathrm{m}}$ values for ATP $(25 \pm 4 \mu \mathrm{M})$ and angiotensin I $(6.6 \pm 0.5 \mathrm{mM})$ exhibited by the viral form of the enzyme (pp60 $0^{\mathrm{v}-\mathrm{src}}$ ) expressed in the Rous-sarcoma-virus-transformed cell line RR1022, which was also determined with the use of monoclonal antibody 327 in immune-complex protein kinase assays. It was not possible to compare the $V_{\max }$ values for pp $60^{\mathrm{v}-\mathrm{src}}$ with those of $\mathrm{pp} 60^{\mathrm{c}-\mathrm{src}}$ because monoclonal antibody 327 did not efficiently recognize pp60 $0^{\text {visc }}$ on Western immunoblots of RR1022-cell extracts. The amount of $\mathrm{pp} 60^{\mathrm{v}-\mathrm{src}}$ protein could not be reliably compared with that of $\mathrm{pp} 60^{\mathrm{c}-\mathrm{src}}$ in the neuroblastoma cells by metabolic labelling with $\left[{ }^{35}\right.$ S $]$ methionine owing to differential labelling of the viral and cellular forms of the enzyme.

\section{DISCUSSION}

By the use of an immune-complex protein kinase assay we show here that the $\mathrm{pp} 60^{\mathrm{c}-\mathrm{src}}$ tyrosine kinase in the mouse neuroblastoma cell line Neuro-2A has a 7-15-fold higher $V_{\max }$ than the fibroblast enzyme, with only minor differences in $K_{\mathrm{m}}$ values for ATP and the phosphoacceptor substrate. These results indicate that the pp60 ${ }^{\mathrm{c}-\mathrm{src}}$ kinase in neuroblastoma cells has a higher turnover number, which would enable it to exhibit enhanced catalytic activity even at the saturating concentrations of ATP found intracellularly.

The greater $k_{\text {cat. }}$ of the neuroblastoma enzyme appears to be a general feature of $p p 60^{c-s r c}$ in cells of neuronal origin. The $\mathrm{pp} 60^{\mathrm{c}-\mathrm{src}}$ kinase from primary cultures of rat cortical neurons exhibited 6-12-fold greater specific activity than the enzyme in rat astrocyte cultures [9]. pp60 $0^{\text {-sre }}$ in human neuroblastoma cell lines shows a 20-40-fold increase in specific activity compared with the enzyme in human glioblastoma cells or fibroblasts [13]. Because these studies were carried out in immunecomplex assays at a single subsaturating concentration of $\mathrm{ATP}-\mathrm{Mg}^{2+}(20 \mu \mathrm{M}$ [13]; $5 \mu \mathrm{M}$ [9]), it was not possible to predict whether differences in specific activity would persist at the saturating concentrations of ATP that are present in cells $(2-3 \mathrm{~mm})$ [28]. Our results showing that pp $60^{\text {c-src }}$ from neuroblastoma Neuro-2A cells has an increased $V_{\max }$ at near-saturating concentrations of ATP suggests that substrate may be turned over to product at a greater rate by $\mathrm{pp} 60^{\mathrm{c} \text {-src }}$ in neuroblastoma cells than by pp60 $0^{\text {-src }}$ in fibroblasts. An increased $V_{\max }$. $(5-20$-fold) has also been reported for $\mathrm{pp} 60^{\text {c-src }}$ bound to polyoma middle $\mathrm{T}$ antigen [27].

The 7-15-fold increased $V_{\max }$ of pp60 ${ }^{\mathrm{c} \text {-sre }}$ kinase in the Neuro-2A neuroblastoma cell line compared with pp60 $0^{\text {-src }}$ in $\mathrm{NIH}$ (pMcsrc/cos)A fibroblasts depends on the relative amounts of $\mathrm{pp} 60^{\mathrm{c}-\mathrm{src}}$ protein measured. The difference in amount of $\mathrm{pp60}{ }^{\mathrm{c}-\mathrm{src}}$ protein in the two cell lines was found to vary from 10 - to 20 -fold, as determined by immunoblotting with monoclonal antibody 327 . Immunoblotting with a different monoclonal antibody, AB src.1, showed 10-26-fold higher concentrations of pp60 ${ }^{\text {c-src }}$ in the fibroblast cell line (results not shown). Thus inaccuracy in measurement of $\mathrm{pp} 60^{\mathrm{c}-\mathrm{src}}$ protein in immunoblotting could decrease the observed differences in $V_{\max }$. by 2.6-fold at most, in which case the neuroblastoma enzyme would still exhibit a greater $k_{\text {cat. }}$. The results reported here may be in error to the extent that the antibodies differentially recognize $p p 60^{\mathrm{c}-\mathrm{src}}$ from 
the two cell lines on immunoblots. However, they are in accord with increased activity of the neuronal form of the enzyme reported by others using $\left[{ }^{35} \mathrm{~S}\right]$ methionine metabolic labelling to measure pp60 $0^{\mathrm{c}-\mathrm{src}}$ protein. Differences in metabolic labelling of the Neuro-2A and NIH(pMcsrc/ cos)A cell lines with ${ }^{35}$ S]methionine and lack of a radioimmunoassay precluded measurement of $\mathrm{pp} 60^{\mathrm{c}-\mathrm{src}}$ protein by an alternative method.

We do not know the nature of the modification

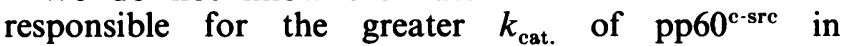
neuroblastoma Neuro-2A cells. $N$-Terminal tyrosine phosphorylation within the pp60 ${ }^{\mathrm{c} \text {-src }}$ molecule has been observed in human neuroblastoma cells [13], and an unidentified $N$-terminal modification of $\mathrm{pp} 60^{\mathrm{e} \text {-src }}$ not due to tyrosine phosphorylation, that may be due to alternative splicing, has been observed in neuronal cultures [9]. However, in neither case has the modification been shown to contribute to the activity of the kinase. Several studies of $p p 60^{\text {-src }}$ from mouse fibroblasts have demonstrated a correlation between dephosphorylation of tyrosine-527, usually accompanied by increased phosphorylation of tyrosine-416, and greater pp60 $0^{\text {s.src }}$ protein kinase activity [29-33]. Cooper \& King [29] observed that dephosphorylation of $\mathrm{pp} 60^{\mathrm{c}-\mathrm{src}}$ by phosphatase treatment in vitro caused a 10-20-fold increase in $\mathrm{pp} 60^{\mathrm{e}-\mathrm{src}}$ protein kinase activity that was attributable to a decreased $K_{\mathrm{m}}$ for ATP as well as an increased $V_{\max }$. Similar $C$-terminal phosphorylations may play a role in the regulation of $\mathrm{pp} 60^{\mathrm{c}-\mathrm{src}}$ protein kinase activity in Neuro-2A cells.

The implications of the results reported here are limited by the nature of the immune-complex protein kinase assay, necessitated by the lack of purified pp60 $0^{\text {c-src }}$. However; the ATP $K_{\mathrm{m}}$ value for pp60 ${ }^{\text {c-src }}$ from RR 1022 cells $(25 \mu \mathrm{M})$ obtained in the immune-complex protein kinase assay with monoclonal antibody 327 approximated a reported ATP $K_{\mathrm{m}}$ value $(50 \mu \mathrm{M})$ obtained with purified $\mathrm{pp} 60^{\mathrm{v}-\mathrm{src}}$ assayed in solution with [Val $\left.{ }^{5}\right]$ angiotensin II as phospho-acceptor substrate [34]. This indicates that the kinase activity of $\mathrm{pp} 60^{\mathrm{c}-\mathrm{src}}$ in the immune complex may not be affected by binding to the monoclonal antibody.

The $K_{\mathrm{m}}$ values for angiotensin I for $\mathrm{pp} 60^{\mathrm{c}-\mathrm{src}}$ from neuroblastoma Neuro-2A cells and fibroblasts were the same, indicating that the phospho-acceptor sites of the two forms of the enzyme were similar. It is possible that differences at the phospho-acceptor site exist that were not revealed by $K_{\mathrm{m}}$ values for the peptide substrate, and that differences in the $K_{\mathrm{m}}$ might be found with phosphoacceptor substrates other than angiotensin I. However, in lieu of a physiological substrate, angiotensin $I$ is suitable for kinetic determinations, because it has a single tyrosine residue. In vitro protein substrates such as $\alpha$ casein are likely to have multiple tyrosine residues that can be phosphorylated by $\mathrm{pp} 60^{\mathrm{c} \text {-src }}$, rendering interpretation of kinetic data difficult. Nonetheless, it will be important to confirm the results presented here with natural cellular substrates, once they are identified, and also to determine if activation of pp60 $0^{\text {c-src }}$ occurs in neuroblastoma Neuro-2A cells in vivo.

The physiological role of the enhanced catalytic efficiency of $\mathrm{pp} 60^{\mathrm{c}-\mathrm{src}}$ kinase in neuroblastoma Neuro-2A cells is not known. The greater $k_{\text {cat. }}$ of pp60 $0^{\mathrm{e}-\mathrm{src}}$ in Neuro$2 \mathrm{~A}$ cells does not appear to involve a genetic alteration of c-src that is responsible for transformation of the neuroblastoma cells. Transfection of NIH 3T3 cells with
Neuro-2A genomic DNA resulted in foci of transformed cells whose DNA could be used in subsequent transfections to obtain secondary foci, indicating the presence of a transforming gene (D. W. Fults \& P. F. Maness, unpublished work). DNA isolated from these secondary foci did not contain multiple copies of the c-src gene when analysed by Southern blotting. Moreover, extracts of transformed cells from the secondary foci did not exhibit elevated concentrations of pp60 $0^{\mathrm{c}-\mathrm{src}}$ on Western blots or increased $\mathrm{pp} 60^{\mathrm{c}-\mathrm{src}}$ kinase activity in immunecomplex protein kinase assays, suggesting that the transforming gene of Neuro-2A cells is not the c-src gene.

The greater $k_{\text {cat. }}$ of $\mathrm{pp} 60^{\mathrm{c}-\mathrm{src}}$ kinase from neuroblastoma cells appears instead to be a normal characteristic of neuronal cells. The expression of $\mathrm{pp} 60^{\mathrm{c}-\mathrm{src}}$ in developing neurons of the neural retina and cerebellum is maximal during the period of neurite outgrowth, and immunoreactivity is concentrated in process-rich regions $[6,7]$. In addition, the ability of $\mathrm{pp} 60^{\mathrm{v}-\mathrm{src}}$ to induce neurite outgrowth in PC12 phaeochromocytoma cells implicates tyrosine kinase activity in process formation and neuronal differentiation [35]. The increased catalytic efficiency of $\mathrm{pp} 60^{\mathrm{c}-\mathrm{src}}$ protein kinase in neuroblastoma cells may therefore be a manifestation of its activity in immature neuronal cells, which could involve neurite extension or some other aspect of neuronal differentiation.

This work was supported by a Public Health Service award (HD20406-01) from the National Institute of Child Health and Human Development. We thank Dr. Joan Brugge for monoclonal antibody 327 and Dr. David Shalloway for the NIH(pMcsrc/cos)A cell line. The excellent work of David Hillsgrove in the initial studies for this project is gratefully acknowledged. P. F. M. is a recipient of an N.I.H. Career Development Award.

\section{REFERENCES}

1. Collett, M. S., Brugge, J. S. \& Erikson, R. L. (1978) Cell 15, 1363-1369

2. Collett, M. S. \& Erikson, R. L. (1978) Proc. Natl. Acad. Sci. U.S.A. 75, 2021-2024

3. Hunter, T. \& Sefton, B. M. (1980) Proc. Natl. Acad. Sci. U.S.A. 77, 1311-1315

4. Cotton, P. C. \& Brugge, J. S. (1983) Mol. Cell. Biol. 3, 1157-1162

5. Levy, B. T., Sorge, L. K., Meymandi, A. \& Maness, P. F. (1984) Dev. Biol. 104, 9-17

6. Fults, D. W., Towle, A. C., Lauder, J. M. \& Maness, P. F. (1985) Mol. Cell. Biol. 5, 27-32

7. Sorge, L. K., Levy, B. T. \& Maness, P. F. (1984) Cell 36, 249-257

8. Maness, P. F. (1986) J. Neurosci. Res. 16, 127-139

9. Brugge, J. S., Cotton, P. C., Queral, A. E., Barrett, J. N., Nonner, D. \& Keane, R. W. (1985) Nature (London) 316, 554-557

10. Maness, P. F., Sorge, L. K. \& Fults, D. W. (1986) Dev. Biol. 117, 83-89

11. Opperman, H., Levinson, A. D., Varmus, H. E., Levintow, L. \& Bishop, J. M. (1979) Proc. Natl. Acad. Sci. U.S.A. 76, 1804-1808

12. Rohrschneider, L. R., Eisenman, R. N. \& Leitch, C. R. (1979) Proc. Natl. Acad. Sci. U.S.A. 76, 4479-4483

13. Bolen, J. B., Rosen, N. \& Israel, M. A. (1985) Proc. Natl. Acad. Sci. U.S.A. 82, 7275-7279 
14. Amano, T., Richelson, E. \& Nirenberg, M. (1972) Proc. Natl. Acad. Sci. U.S.A. 69, 258-263

15. Augusti-Tocco, G. \& Sato, G. (1969) Proc. Natl. Acad. Sci. U.S.A. 64, 311-315

16. Schubert, D., Humphreys, S., Baroni, C. \& Cohn, M. (1969) Proc. Natl. Acad. Sci. U.S.A. 64, 316-323

17. Klebe, R. J. \& Ruddle, F. H. (1969) J. Cell Biol. 43, 69A

18. Johnson, P. J., Coussens, P. M., Danko, A. V. \& Shalloway, D. (1985) Mol. Cell. Biol. 5, 1073-1083

19. Lowry, O. H., Rosebrough, N. J., Farr, A. L. \& Randall, R. J. (1951) J. Biol. Chem. 193, 265-275

20. Lipsich, L. A., Lewis, A. J. \& Brugge, J. S. (1983) J. Virol. 48, 352-360

21. Glass, D. B., Masarachia, R. A., Feramisco, J. R. \& Kemp, B. E. (1978) Anal. Biochem. 87, 566-575

22. Laemmli, U. K. (1970) Nature (London) 227, 680-685

23. Towbin, H., Staehelin, T. \& Gordon, J. (1979) Proc. Natl. Acad. Sci. U.S.A. 76, $4350-4354$

24. Golden, A., Nemeth, S. P. \& Brugge, J. S. (1986) Proc. Natl. Acad. Sci. U.S.A. 83, 852-856

Received 20 January 1987/15 June 1987; accepted 17 August 1987
25. Maness, P. F., Perry, M. E. \& Levy, B. T. (1983) J. Biol. Chem. 258, 4055-4058

26. Wilkinson, G. N. (1961) J. Biochem. (Tokyo) 80, 324332

27. Courtneidge, S. A. (1985) EMBO J. 4, 1471-1477

28. Rapaport, E. \& Zamecnik, P. C. (1976) Proc. Natl. Acad. Sci. U.S.A. 73, 3984-3988

29. Cooper, J. A. \& King, C. S. (1986) Mol. Cell. Biol. 6, 4467-4477

30. Kmiecik, T. E. \& Shalloway, D. (1987) Cell 49, 65-73

31. Piwnica-Worms, H., Saunders, K. B., Roberts, T. M., Smith, A. E. \& Cheng, S. H. (1987) Cell 49, 75-82

32. Cartwright, C. A., Eckhart, W., Simon, S. \& Kaplan, P. L. (1987) Cell 49, 83-91

33. Ryder, J. W. \& Gordon, J. A. (1987) Mol. Cell. Biol. 7, 1139-1147

34. Wong, T. W. \& Goldberg, A. R. (1983) J. Biol. Chem. 258, 1022-1025

35. Alemá, S., Casabore, P., Agostini, E. \& Tatò, F. (1985) Nature (London) 316, 557-559 